\title{
Article \\ Effects of SiC Fibers and Laminated Structure on Mechanical Properties of Ti-Al Laminated Composites
}

\author{
Chenyang Hou, Shouyin Zhang *, Zhijian Ma, Baiping Lu and Zhenjun Wang
}

check for

updates

Citation: Hou, C.; Zhang, S.; Ma, Z.; Lu, B.; Wang, Z. Effects of SiC Fibers and Laminated Structure on

Mechanical Properties of Ti-Al

Laminated Composites. Materials 2021, 14, 1323. https://doi.org/ $10.3390 / \mathrm{ma} 14061323$

Received: 20 February 2021

Accepted: 8 March 2021

Published: 10 March 2021

Publisher's Note: MDPI stays neutral with regard to jurisdictional claims in published maps and institutional affiliations.

Copyright: (c) 2021 by the authors. Licensee MDPI, Basel, Switzerland. This article is an open access article distributed under the terms and conditions of the Creative Commons Attribution (CC BY) license (https:/ / creativecommons.org/licenses/by/ $4.0 /)$.
School of Aeronautic Manufacturing Engineering, Nanchang Hangkong University, Nanchang 330063, China; houchenyang2157@163.com (C.H.); mazhijian2020@163.com (Z.M.); 1bp029@163.com (B.L.); wangzhj@nchu.edu.cn (Z.W.)

* Correspondence: zhangsy@nchu.edu.cn; Tel.: +86-136-4708-1021

Abstract: $\mathrm{Ti} / \mathrm{Ti}-\mathrm{Al}$ and $\mathrm{SiC}_{\mathrm{f}}$-reinforced $\mathrm{Ti} / \mathrm{Ti}-\mathrm{Al}$ laminated composites were fabricated through vacuum hot-pressure using pure $\mathrm{Ti}$ foils, pure $\mathrm{Al}$ foils and $\mathrm{SiC}$ fibers as raw materials. The effects of $\mathrm{SiC}$ fiber and a laminated structure on the properties of Ti-Al laminated composites were studied. A novel method of fiber weaving was implemented to arrange the SiC fibers, which can guarantee the equal spacing of the fibers without introducing other elements. Results showed that with a higher exerted pressure, a more compact structure with fewer Kirkendall holes can be obtained in $\mathrm{SiC}_{\mathrm{f}}$-reinforced $\mathrm{Ti} / \mathrm{Ti}-\mathrm{Al}$ laminated composites. The tensile strength along the longitudinal direction of fibers was about $400 \pm 10 \mathrm{MPa}$, which was $60 \%$ higher compared with the fabricated Ti/Ti-Al laminated composites with the same volume fraction $(60 \%)$ of the Ti layer. An in situ tensile test was adopted to observe the deformation behavior and fracture mechanisms of the $\mathrm{SiC}_{\mathrm{f}}$-reinforced $\mathrm{Ti} / \mathrm{Ti}$ Al laminated composites. Results showed that microcracks first occurred in the Ti-Al intermetallic layer.

Keywords: SiC fiber; laminated structure; Ti-Al laminated composite; in situ tensile; mechanical properties

\section{Introduction}

Due to presenting several advantages such as low density, high modulus of elasticity, good high-temperature creep strength and oxidation resistance, titanium aluminide (TiAl) based alloys have great potential in aerospace applications [1-3]. However, they suffer from a major challenge of low room temperature ductility. This was considered to be a significant barrier for these classes of alloys for use in structural components.

Inspired by the structural biological materials such as the abalone shell, animal bones and mammal teeth, etc. [4,5], Ti intermetallic multilayered composites [6-10], which possess improved toughness, fracture resistance and excellent creep resistance and have been extensively researched. By micro-, meso- and macrostructure designing and tailoring, specific functionality of Ti intermetallic multilayered composites can be achieved. The superior specific properties of this class of composites make them extremely attractive for high-performance aerospace applications [11]. Meanwhile, continuous SiC fibers with outstanding properties of high strength, high modulus and low density have successfully been introduced into titanium matrix material through the vacuum high-temperature pressing (VHP) method [4,12]. It has been found that SiC fiber-reinforced Ti intermetallic multilayered composites possess excellent toughness and fracture resistance.

An $\mathrm{SiC}_{\mathrm{f}}$-reinforced $\mathrm{Ti}$ intermetallic multilayers composite was fabricated by Yu et al. [13]. Results showed that along the longitudinal direction of SiC fibers, the ultimate tensile and flexural strength and fracture toughness of the composite increased by $53 \%, 74 \%$ and $75 \%$, respectively, while the elongation remained almost similar to the Ti intermetallic multilayer composite. Zhu et al. [4] fabricated a Ti intermetallic multilayered $/ \mathrm{SiC}_{\mathrm{f}}$-reinforced Ti matrix composite and found that with the introduction of SiC fibers, the tensile and the flexural 
strength of the hybrid composite along the longitudinal direction of the fibers increased by $57 \%$ and $92 \%$ compared with the composite without $\mathrm{SiC}$ fiber. Wang et al. [14] investigated the fatigue behavior and damage modeling of SCS-6/titanium/titanium aluminide hybrid laminated composite. Compared with SCS-6/Ti-6-4 composite, the SCS-6/Ti-6-4/Ti-25-10 hybrid laminated composite possessed improved fatigue behavior. Zhang et al. [15] also studied the mechanical behaviors and failure mechanisms of $\mathrm{SiC}_{\mathrm{f}}$-reinforced $\mathrm{Ti} / \mathrm{Ti}_{2} \mathrm{AlNb}$ laminated composite. The researches above show that $\mathrm{SiC}_{\mathrm{f}}$-reinforced Ti intermetallic laminated composites provide an effective approach for tailoring mechanical propertied. This can be attributed to the crack deflection ability of the Ti intermetallic multilayered structure, as well as the reinforcement effect of continuous SiC fibers.

It was found that the majority of studies focused on strengthening ductile Ti layers with SiC fibers, followed by hybridization with intermetallic layers. This is principally because the ductile layer can serve as the compliant layer to suppress the initiation and propagation of residual stress placed on cracks near the interface [14]. Lin et al. [16] prepared an $\mathrm{SiC}_{\mathrm{f}}-\mathrm{Ti} / \mathrm{Al}_{3} \mathrm{Ti}$ laminated composite by using the vacuum hot-pressing sintering method and found that $\mathrm{SiC}$ fibers can provide strengthening and toughening effects for the brittle intermetallic and the laminated composites. The strengthening mechanism of the $\mathrm{SiC}_{\mathrm{f}}$-reinforced intermetallic layer still needs to be clarified. Meanwhile, reaction products, thickness, bonding strength of the interface that between $\mathrm{SiC}$ fiber and its surrounding intermetallic matrix, as well as the fiber damage, play critical roles in the mechanical properties of the $\mathrm{SiC}_{\mathrm{f}}$-reinforced $\mathrm{Ti} / \mathrm{TiAl}$ laminated composite. The fiber arrangement and the enhancement mechanism need to be further investigated.

Hence, an $\mathrm{SiC}_{\mathrm{f}}$-reinforced $\mathrm{Ti} / \mathrm{Ti}-\mathrm{Al}$ laminated composite was designed and fabricated with commercial pure Ti foils, $\mathrm{Al}$ foils and SiC fibers by the VHP method. The interface between the SiC fiber and the intermetallic matrix was investigated. Tensile tessst and three-point bending test were adopted to evaluate the mechanical properties of the composites. The deformation behavior and fracture mechanisms of the $\mathrm{SiC}_{\mathrm{f}}$-reinforced $\mathrm{Ti} / \mathrm{Ti}-\mathrm{Al}$ laminated composite were studied by applying an in situ tensile test. Furthermore, the $\mathrm{Ti} / \mathrm{Ti}-\mathrm{Al}$ laminated composite was fabricated and investigated for comparison.

\section{Experimental Procedures}

\subsection{Structure Design}

Commercial pure Ti foils (200 $\mu \mathrm{m}$ thick), pure Al foils (20, 100, $200 \mu \mathrm{m}$ thick) were cut into round foils with diameters of $100 \mathrm{~mm}$. Table 1 shows the chemical compositions of the selected materials. $\mathrm{SiC}$ fibers fabricated by Beijing Institute of Aeronautical Materials (China) were chosen as the reinforcement component. These fibers have diameters of $120 \mu \mathrm{m}$ with a tungsten core $(16 \mu \mathrm{m}$ in diameter $)$ and a layer of $\beta$-SiC $(50 \mu \mathrm{m}$ thick), as shown in Figure 1. In addition, a layer of carbon $(2 \mu \mathrm{m})$ was coated by chemical vapor deposition (CVD) to inhibit the reaction. The Ti foils were cleaned in aqueous HF solution (10 vol.\%) while the $\mathrm{Al}$ foils were etched in aqueous $\mathrm{NaOH}$ solution (10 wt.\%) for $2 \mathrm{~min}$. Subsequently, the materials were rinsed with alcohol and processed with ultrasonic cleaning in distiller water, then were dried immediately for further preparation.

Table 1. Chemical compositions of TA1 titanium and 1060 aluminum alloy (wt.\%).

\begin{tabular}{cc}
\hline Materials & Composition (\%) \\
\hline TA1 & Ti: Margin $\mathrm{Fe}<0.13, \mathrm{C}<0.012, \mathrm{~N}<0.003, \mathrm{O}<0.11, \mathrm{H}<0.003$ \\
$1060 \mathrm{Al}$ & $\mathrm{Al}:$ Margin $\mathrm{Si} 0.25, \mathrm{Fe} 0.35, \mathrm{Cu} 0.05, \mathrm{Mn} 0.3, \mathrm{Mg} 0.03, \mathrm{Zn} 0.05, \mathrm{Ti} 0.03$ \\
\hline
\end{tabular}




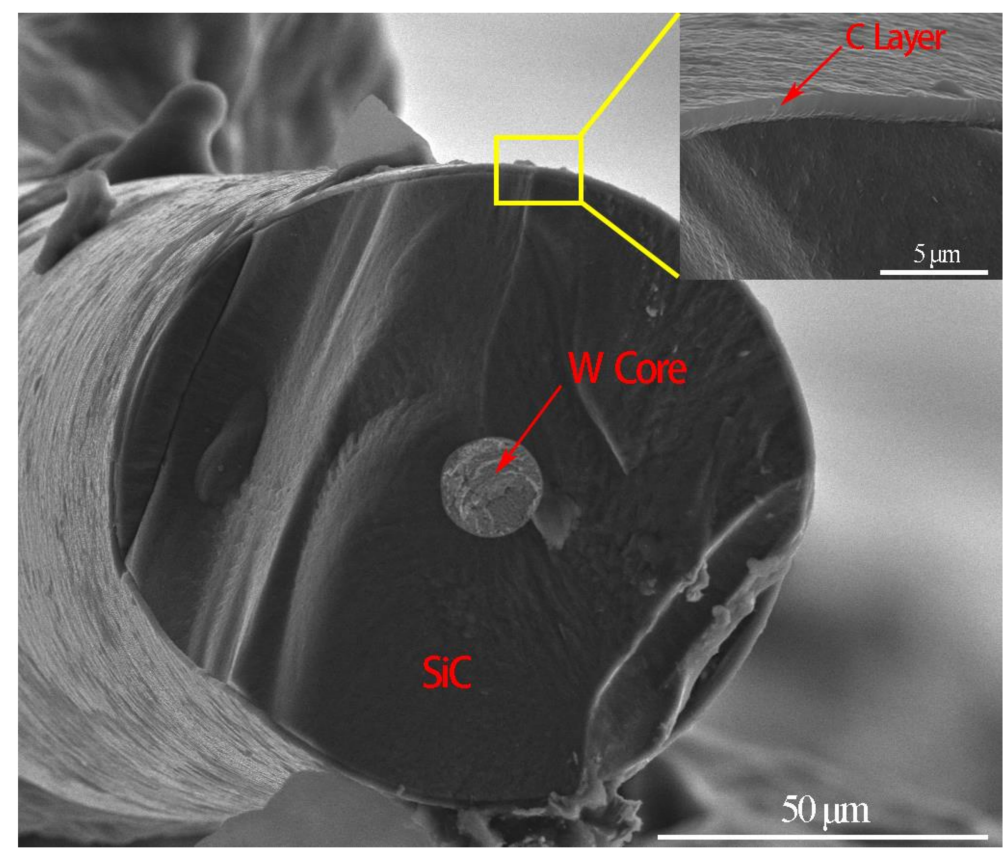

Figure 1. Morphology of SiC fiber.

In order to avoid fiber aggregation in the prepared $\mathrm{SiC}_{\mathrm{f}}$-reinforced $\mathrm{Ti} / \mathrm{Ti}-\mathrm{Al}$ laminated composite, a novel method of fiber weaving was implemented. In this method, equally spaced predrilled holes were drilled into the Al foils (with thickness $20 \mu \mathrm{m}$ ) by a steel needle with $\Phi 200 \mu \mathrm{m}$. Then the fibers travelled up and down the foil material through the drilled holes (Figure 2a). In this work, the spacing is $5 \mathrm{~mm}$ in the $X$ direction and $20 \mathrm{~mm}$ in the $\mathrm{Y}$ direction. Fiber braids with $5 \mathrm{~mm}$ equal spacing were prepared as shown in Figure $2 b$.

(a)

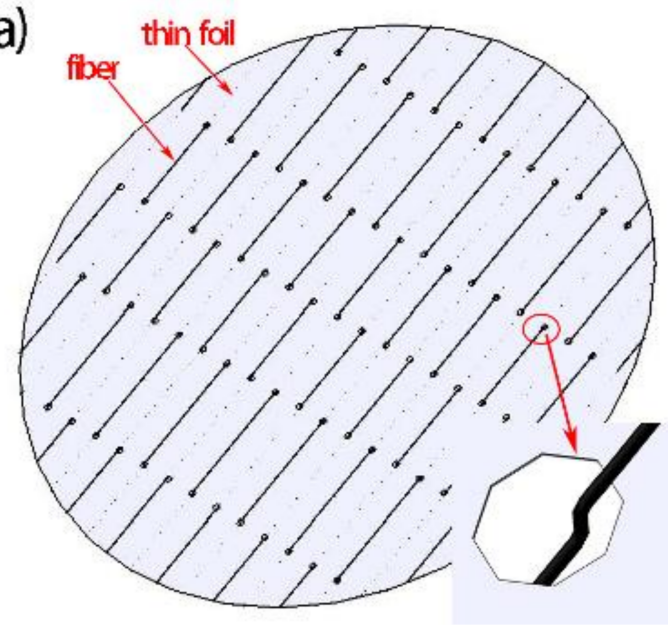

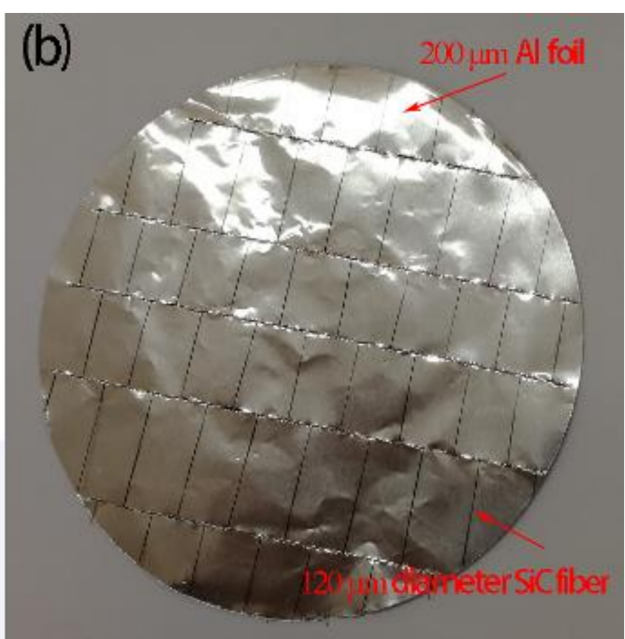

Figure 2. Fiber braid: (a) schematic illustration; (b) fiber braid.

The metallic foils and SiC fiber braids were stacked according to the schematic illustration in Figure 3. Three laminated structures were used: Ti-Al-Ti (Figure 3a), Ti-Al$\mathrm{SiC}_{\mathrm{f}}$-Al-Ti (Figure 3b Pattern A) and Ti-SiC $\mathrm{f}_{\mathrm{f}}-\mathrm{Al}-\mathrm{SiC}_{\mathrm{f}}-\mathrm{Ti}$ (Figure $3 \mathrm{~b}$ Pattern B). The volume fraction of $\mathrm{Ti}$ layers was about $55 \%$ as designed in the preform. Among them, the $\mathrm{Ti} / \mathrm{Ti}-\mathrm{Al}$ laminated composite used the "Ti-Al-Ti" laminated structures, while the $\mathrm{SiC}_{\mathrm{f}}$-reinforced $\mathrm{Ti} / \mathrm{Ti}-\mathrm{Al}$ laminated composite was made up of Pattern A and Pattern B. 


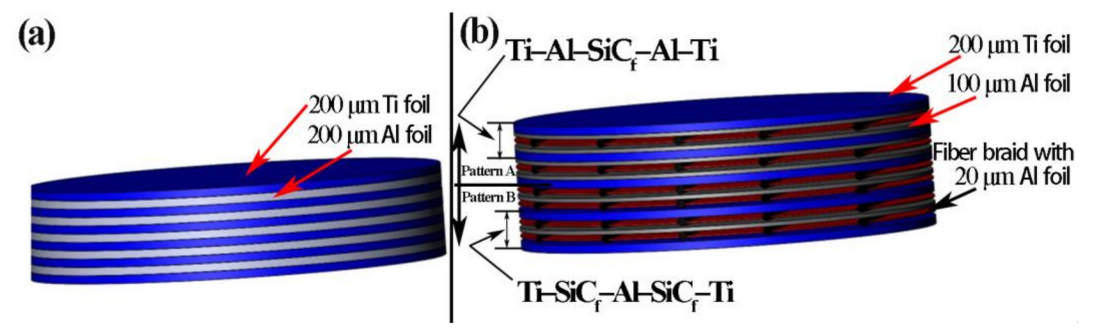

Figure 3. Schematic illustration of the stacking sequence: (a) $\mathrm{Ti}-\mathrm{Al}-\mathrm{Ti}$; (b) Pattern $\mathrm{A}$ : $\mathrm{Ti}-\mathrm{Al}-\mathrm{SiC} \mathrm{f}_{\mathrm{f}} \mathrm{Al}-\mathrm{Ti}$ and Pattern B: Ti-SiC $\mathrm{f}-\mathrm{Al}-\mathrm{SiC}_{\mathrm{f}}-\mathrm{Ti}$.

\subsection{Sintering Process}

The prepared assembly was placed in a graphite mold and was subsequently moved into a vacuum hot-press furnace for sintering. The preparation process includes three steps, as shown in Figure 4.

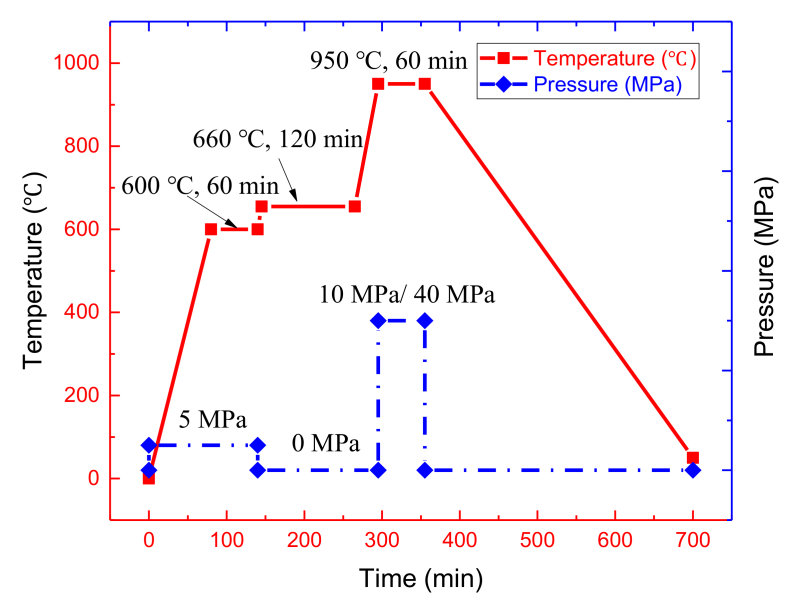

Figure 4. Schematic illustration of the sintering parameters.

Firstly, the temperature was raised to $600{ }^{\circ} \mathrm{C}$ at a rate of $10{ }^{\circ} \mathrm{C} / \mathrm{min}$ and held for $60 \mathrm{~min}$ under a pressure of $5 \mathrm{MPa}$ to achieve a primary combination between the Ti and $\mathrm{Al}$ foils. Secondly, the temperature increased to $660^{\circ} \mathrm{C}$ (the melting temperature of pure aluminum) for $2 \mathrm{~h}$ to ensure that $\mathrm{Al}$ foils were consumed completely, while the pressure was decreased to $0 \mathrm{MPa}$ to avoid the expulsion of the molten aluminum. Finally, the temperature and pressure increased to $950^{\circ} \mathrm{C}$ and $10 \mathrm{MPa}$ for one hour for the $\mathrm{Ti} / \mathrm{Ti}-\mathrm{Al}$ laminated composite, or $950{ }^{\circ} \mathrm{C}$ and $40 \mathrm{MPa}$ for one hour for the $\mathrm{SiC}_{\mathrm{f}}$-reinforced $\mathrm{Ti} / \mathrm{Ti}$ $\mathrm{Al}$ laminated composite. Then, the exerted pressure was released, and the temperature decreased to room temperature in the furnace. Schematic illustration of the sintering parameters is presented in Figure 4 .

\subsection{Materials Characterization}

After VHP, specimens used for characterization were cut from the synthesized samples with a wire electrical discharge machine (DK7355, Xiongfeng Machinery Co., Ltd., Ningbo, China), and were inlaid into epoxy resin. Subsequently, the specimens were ground using sandpaper and polished to a smooth mirror surface using diamond paste. Then, metallographic specimens were etched by reagent ( 5 vol. $\% \mathrm{HF}+15$ vol. $\% \mathrm{HNO}_{3}+80$ vol. $\%$ $\mathrm{H}_{2} \mathrm{O}$ ).

Optical microscopy (OM, IM 300, China) was performed for the microstructure observation. A Field Emission Scanning Electron Microscope (SEM; FEI Nova Nano SEM450, Hillsboro, OR, USA) equipped with an Energy Dispersive X-ray Spectrometer (EDXS, INCA 250X-Max 50, Oxford, UK) was used for the microstructure observation and local composition analysis. X-ray diffraction (XRD, D8 ADVANCE, Brooke, Germany) was performed for the phase identification. 


\subsection{Mechanical Properties Measurements}

Quasi-static tensile tests were carried out on the fabricated $\mathrm{Ti} / \mathrm{Ti}-\mathrm{Al}$ and $\mathrm{SiC}_{\mathrm{f}}$-reinforced $\mathrm{Ti} / \mathrm{Ti}-\mathrm{Al}$ laminated composites at room temperature with a loading rate of $0.2 \mathrm{~mm} / \mathrm{min}$. Test specimens were machined along the $\mathrm{SiC}$ fibers direction using wire electrical discharge. Subsequently, their surfaces were polished. The gauge sections were $26 \mathrm{~mm}$ in length, $6 \mathrm{~mm}$ in width and $3 \mathrm{~mm}$ in thickness, as illustrated in Figure 5a. The strain sheet was affixed to both sides of the specimen, and the strain value was recorded by the strain gauge.

(a)

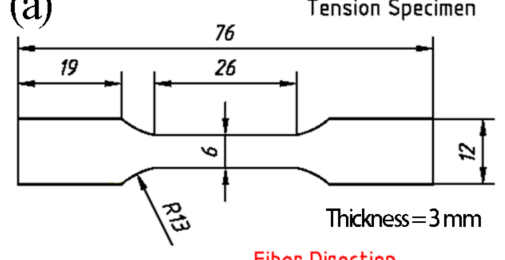

(c)
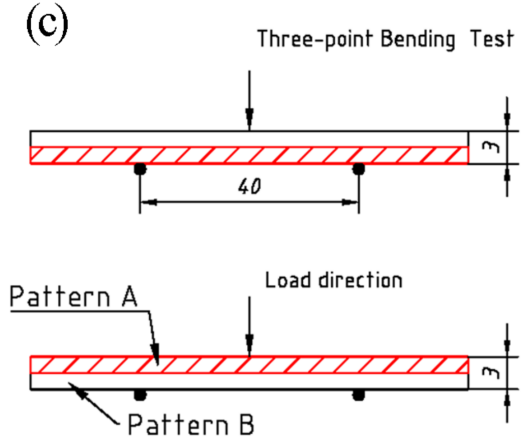

Pattern B

(b)
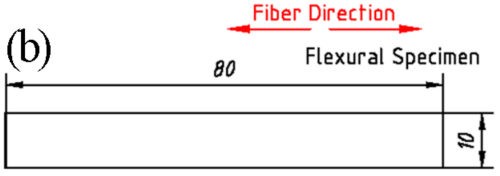

Figure 5. Schematic illustrations of the specimens (units: $\mathrm{mm}$ ): (a) tensile specimen; (b) flexural specimen; (c) three-point bending test (Pattern A: Ti-Al-SiC $\mathrm{f}_{\mathrm{f}}-\mathrm{Al}-\mathrm{Ti}$; Pattern B: Ti-SiC $\mathrm{f}-\mathrm{Al}-\mathrm{SiC} \mathrm{f}_{\mathrm{f}}-\mathrm{Ti}$ ).

For the three-point bending test, the constant loading rate was $2 \mathrm{~mm} / \mathrm{min}$. The specimens were $80 \mathrm{~mm}$ in length, $10 \mathrm{~mm}$ in width and $3 \mathrm{~mm}$, as shown in Figure $5 \mathrm{~b}$. The specimens of SiCf-reinforced $\mathrm{Ti} / \mathrm{Ti}-\mathrm{Al}$ laminated composites with two different loading modes are shown in Figure 5c. The supporting distance is $40 \mathrm{~mm}$. After tests, the fracture surfaces of tensile specimens were observed by SEM.

In situ tensile testing of specimen in SEM (MINI-MTS2000, Qiyue Technology Co., Ltd., Hangzhou, Zhejiang Province, China) was applied with a loading rate of $5 \mu \mathrm{m} / \mathrm{s}$. In order to better observe the fracture and crack extension behavior of the $\mathrm{SiC}_{\mathrm{f}}$-reinforced $\mathrm{Ti} / \mathrm{Ti}-\mathrm{Al}$ laminated composites, each surface was polished, especially the observation surface-i.e., the cross section of the specimen that is $10 \mathrm{~mm}$ in gauge length (Figure 6).

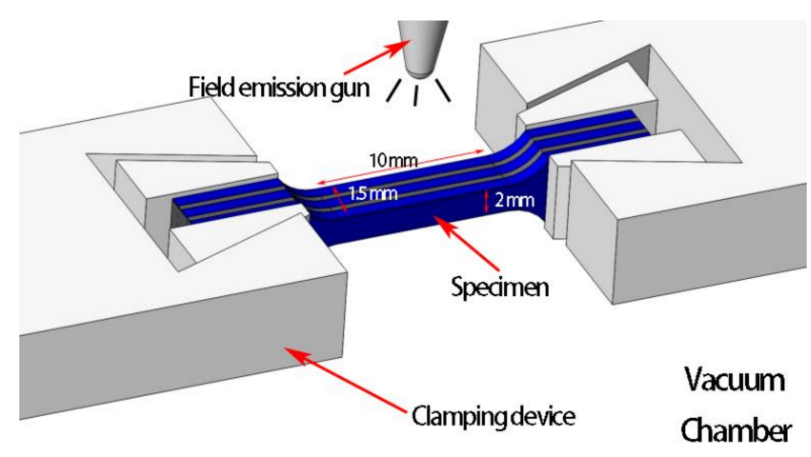

Figure 6. Schematic illustrations of the in-situ tension specimen (unit: $\mathrm{mm}$ ).

\section{Results and Discussion}

\subsection{Microstructure Characterization}

Figure $7 \mathrm{a}, \mathrm{b}$ present the transverse section of the fabricated $\mathrm{SiC}_{\mathrm{f}}$-reinforced $\mathrm{Ti} / \mathrm{Ti}-\mathrm{Al}$ laminated composite. The layers with dark colors are the titanium, while the layers with light color are the formed intermetallic, among which are the scattered SiC fibers (black dots). As described above, two different arrangements were designed in the preform: $\mathrm{Ti}-\mathrm{Al}-\mathrm{SiC}_{\mathrm{f}}-\mathrm{Al}-\mathrm{Ti}$ and $\mathrm{Ti}-\mathrm{SiC}_{\mathrm{f}}-\mathrm{Al}-\mathrm{SiC}_{\mathrm{f}}-\mathrm{Ti}$. Figure $7 \mathrm{~b}$ shows the structure illustration of the fabricated laminated composite. It can be found that the $\mathrm{SiC}$ fibers in Pattern $\mathrm{A}$ are almost at equal distances $(5.0 \pm 0.5 \mathrm{~mm})$ along the laminate direction. This means that the fiber 
intervals can be guaranteed by using the fiber braid, as shown in Figure 2, while in Pattern $\mathrm{B}$, two layers of fiber braid were placed between the $\mathrm{Ti}$ foils $\left(\mathrm{Ti}-\mathrm{SiC} \mathrm{f}_{\mathrm{f}}-\mathrm{Al}-\mathrm{SiC} \mathrm{f}-\mathrm{Ti}\right)$. With the melt and reaction of $\mathrm{Al}$ foils, two layers of fiber braids were pressed together, resulting in $\mathrm{SiC}$ fiber aggregation.

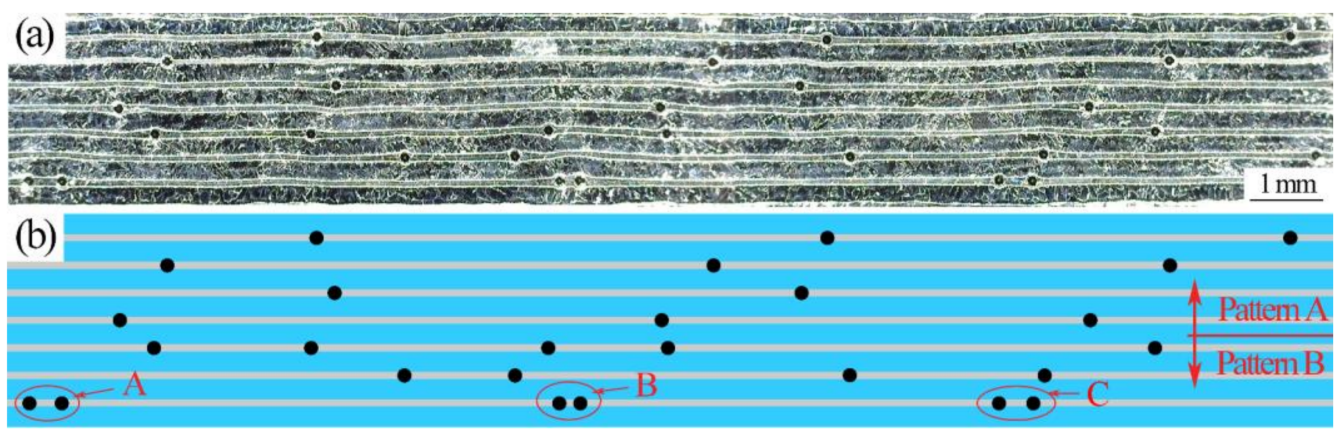

Figure 7. Transverse section of $\mathrm{SiC}_{\mathrm{f}}$-reinforced $\mathrm{Ti} / \mathrm{Ti}-\mathrm{Al}$ laminated composites: (a) Optical microscopy (OM) image; (b) structure illustration.

Both the actual volume fractions of the $\mathrm{Ti}$ layer in the $\mathrm{Ti} / \mathrm{Ti}-\mathrm{Al}$ and $\mathrm{SiC}_{\mathrm{f}}$-reinforced $\mathrm{Ti} / \mathrm{Ti}-\mathrm{Al}$ laminated composites were approximately $60 \%$, as measured. This is $5 \%$ higher than the theoretical volume fraction, which was mainly due to the reaction and mutual diffusion of aluminum and titanium atoms at high temperatures.

Previous studies $[17,18]$ have demonstrated that due to the different diffusion coefficient of $\mathrm{Ti}$ and $\mathrm{Al}$ atoms, Kirkendall holes will emerge when fabricating $\mathrm{Ti} / \mathrm{Ti}-\mathrm{Al}$ laminated composites. Figure $8 \mathrm{a}, \mathrm{b}$ present microstructures of the Ti/Ti-Al laminated composite, while Figure $8 \mathrm{c}-\mathrm{f}$ show the microstructures of the $\mathrm{SiC}_{\mathrm{f}}$-reinforced $\mathrm{Ti} / \mathrm{Ti}-\mathrm{Al}$ laminated composite. In $\mathrm{Al} / \mathrm{Ti}$ diffusion couple, during the net movement of atoms from $\mathrm{Al}$ to $\mathrm{Ti}$ caused by the different diffusion coefficient, vacancies will form and diffuse from the Ti toward Al layer $[17,18]$. It can be observed that obvious Kirkendall holes existed in the $\mathrm{Ti} / \mathrm{Ti}-\mathrm{Al}$ laminated composite (Figure $8 \mathrm{~b}$ ). By comparison, Kirkendall holes in the $\mathrm{SiC}_{\mathrm{f}^{-}}$ reinforced $\mathrm{Ti} / \mathrm{Ti}-\mathrm{Al}$ laminated composites were much lower in number (Figure $8 \mathrm{~d}$ ). This may be attributed to the larger exerted pressure (40 MPa) during the fabricating processes, compared to the $10 \mathrm{MPa}$ pressure applied in the $\mathrm{Ti} / \mathrm{Ti}-\mathrm{Al}$ laminated composites.
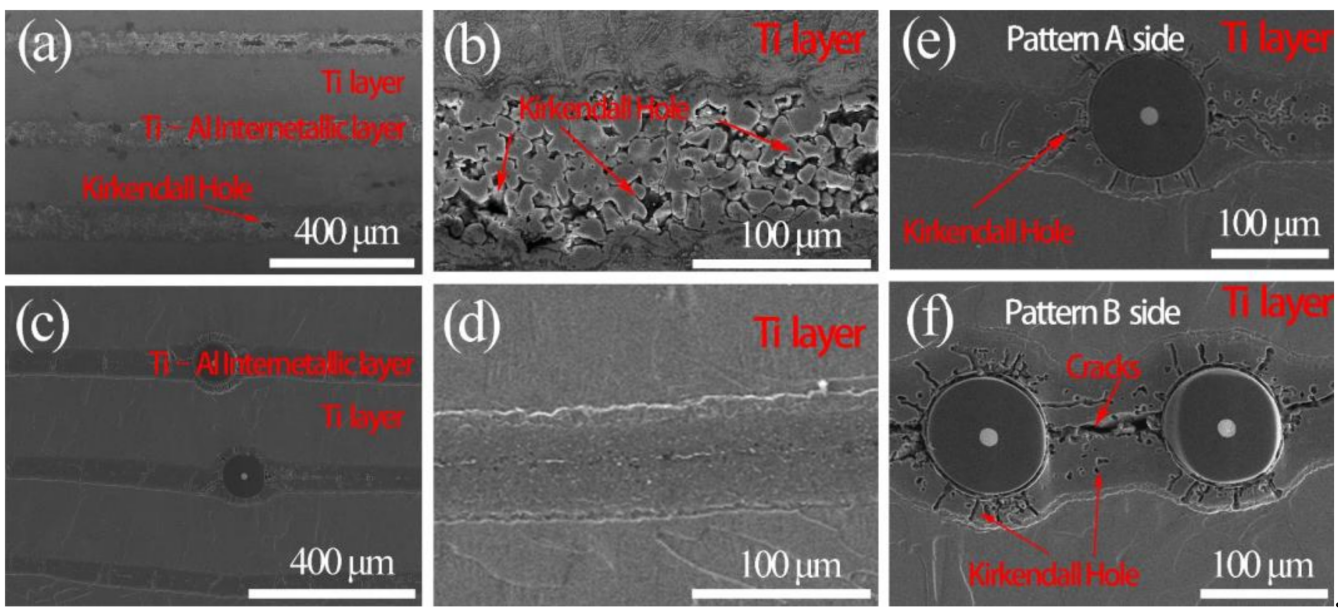

Figure 8. Microstructure of the fabricated laminated composites: (a), (b) Ti/Ti-Al laminated composite; $(\mathbf{c}-\mathbf{f}) \mathrm{SiC}_{\mathrm{f}}$-reinforced $\mathrm{Ti} / \mathrm{Ti}-\mathrm{Al}$ laminated composites.

Figure 8e,f show the microstructures of $\mathrm{SiC}_{\mathrm{f}}$-reinforced $\mathrm{Ti} / \mathrm{Ti}-\mathrm{Al}$ laminated composites corresponding to Pattern A and Pattern B, as depicted in Figure 3b. SiC fiber aggregation occurred on the Pattern B side. With small spacing between the SiC fibers, more cracks 
emerged (Figure 8f). This means that the "Ti-Al-SiC $\mathrm{f}_{\mathrm{f}}-\mathrm{Al}-\mathrm{Ti}^{\prime}$ laminated structure (Pattern A) should be preferred to obtain an equal spacing of the fiber arrangement.

Figure 9 shows the $\mathrm{X}$-ray diffraction analysis of the laminated composites. The results suggest that the intermetallic phases contain $\mathrm{Ti}_{3} \mathrm{Al}, \mathrm{TiAl}, \mathrm{TiAl}_{2}$ and $\mathrm{TiAl}_{3}$. Additionally, $\mathrm{Al}$ phases were not found in XRD patterns, which indicates that $\mathrm{Al}$ was completely consumed in the sintering process.

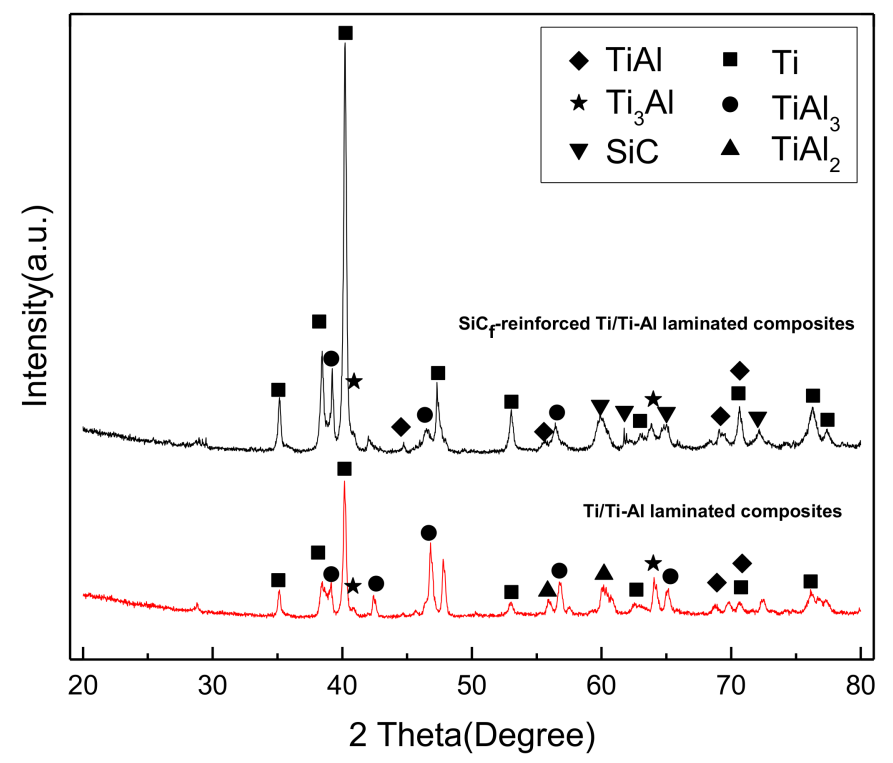

Figure 9. X-ray diffraction (XRD) patterns of the fabricated $\mathrm{Ti} / \mathrm{Ti}-\mathrm{Al}$ laminated composites.

Figure 10a,b depict the phase composition, phase distribution and interfacial evolution of the $\mathrm{Ti} / \mathrm{Ti}-\mathrm{Al}$ interface zone. Typically, EDXS line scans were made along the yellow line to investigate the chemical compositions of different layers. Afterward, EDXS point scanning was used to determine the chemical compositions of the four marked points depicted in Figure 10a,b. The analysis results are shown in Table 2. These reveal that the corresponding phases are $\mathrm{Ti}, \mathrm{Ti}_{3} \mathrm{Al}, \mathrm{TiAl}_{2}$ and $\mathrm{TiAl}_{3}$, respectively. The results are consistent with previous studies $[4,19]$.
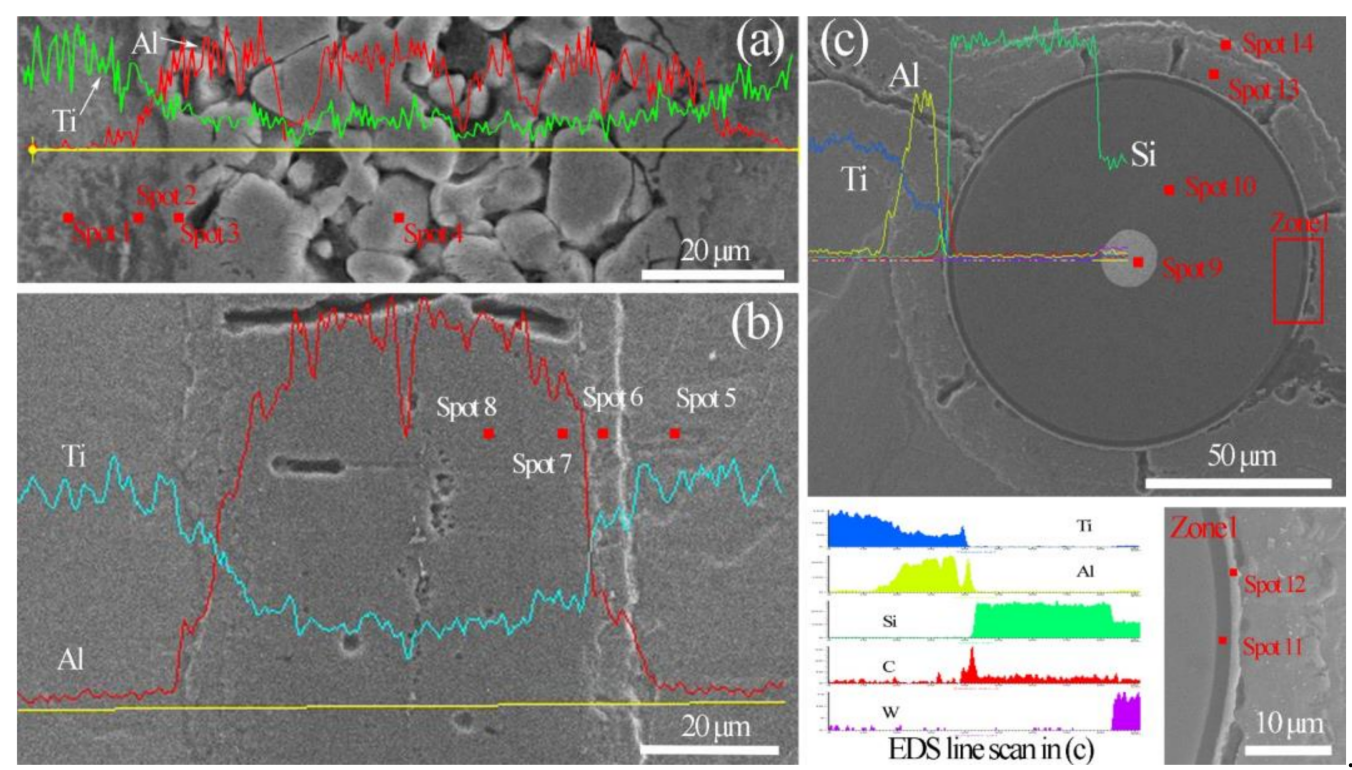

Figure 10. EDXS results: (a) Ti/Ti-Al laminated composites, (b) $\mathrm{SiC}_{\mathrm{f}}$-reinforced $\mathrm{Ti} / \mathrm{Ti}-\mathrm{Al}$ laminated composites, and (c) $\mathrm{SiC}_{\mathrm{f}} / \mathrm{Ti}-\mathrm{Al}$ interface. 
Table 2. Typical chemical compositions of the Ti/Ti-Al interface zone detected by Energy Dispersive X-ray Spectrometry (EDXS).

\begin{tabular}{ccccccc}
\hline Point No. & Ti & Al & Point No. & Ti & Al & Phase \\
\hline Spot 1 & 95 & 5 & Spot 5 & 96 & 4 & $\mathrm{Ti}$ \\
Spot 2 & 70 & 30 & Spot 6 & 71 & 29 & $\mathrm{Ti}_{3} \mathrm{Al}$ \\
Spot 3 & 35 & 65 & Spot 7 & 34 & 66 & $\mathrm{TiAl}_{2}$ \\
Spot 4 & 24 & 76 & Spot 8 & 25 & 75 & $\mathrm{TiAl}_{3}$ \\
\hline
\end{tabular}

It can also observe that the concentrations of the elements Ti and $\mathrm{Al}$ present significant gradient changes in the $\mathrm{SiC}_{\mathrm{f}}$-reinforced $\mathrm{Ti} / \mathrm{Ti}-\mathrm{Al}$ laminated composites (Figure $10 \mathrm{~b}$ ) in contrast with the Ti/ Ti-Al laminated composites (Figure 10a). A conclusion can be made that a more stable $\mathrm{TiAl}_{3}$ phase can be obtained with an exerted pressure $40 \mathrm{MPa}$ in the sintering process.

Figure $10 \mathrm{c}$ presents the interface of the $\mathrm{SiC}$ fiber and intermetallic matrix. An intact $\mathrm{C}$ coating can be found on the $\mathrm{SiC}$ fiber surface, which prevents the fiber damage in the laminated composites. Meanwhile, a clear thin gray layer (about $1 \mu \mathrm{m}$ thick) was formed on the Ti-Al intermetallic side (Figure 10c). According to the results of the line scanning in Figure 10c and the point scanning in Table 3 (Spot 12), the reaction layer can be identified as $\mathrm{TiC}$ and $\mathrm{Al}_{4} \mathrm{C}_{3}$, as demonstrated in previous reports $[4,12,20]$. However, they were not detected in XRD (Figure 9) due to the low contents.

Table 3. Typical chemical compositions of the $\mathrm{SiC}_{\mathrm{f}} / \mathrm{Ti}-\mathrm{Al}$ interface area detected by EDXS.

\begin{tabular}{cccccc}
\hline Point No. & Ti & Al & Si & C & W \\
\hline Spot 9 & - & - & - & - & 100 \\
Spot 10 & - & - & 36 & 64 & - \\
Spot 11 & 0 & 0 & 5 & 95 & - \\
Spot 12 & 28 & 8 & 3 & 61 & - \\
Spot 13 & 34 & 66 & - & - & - \\
Spot 14 & 72 & 28 & - & - & - \\
\hline
\end{tabular}

Figure 10c shows holes with short strips around $\mathrm{SiC}$ fibers and Figure 10b shows that similar morphologies exist in Ti-Al intermetallic compound layer. This is due to the Ti and $\mathrm{Al}$ atomic diffusion coefficient differences, resulting in the formation of Kirkendall holes.

\subsection{Mechanical Properties}

Table 4 shows the tensile strength and flexural strength of the fabricated laminated composites. Compared with $\mathrm{Ti} / \mathrm{Ti}-\mathrm{Al}$ laminated composites, the tensile strength of $\mathrm{SiC}_{\mathrm{f}^{-}}$ reinforced $\mathrm{Ti} / \mathrm{Ti}-\mathrm{Al}$ laminated composite increases by $60 \%$, while there is no significant increase in flexural strength. The three-point bending test of $\mathrm{SiC}_{\mathrm{f}}$-reinforced $\mathrm{Ti} / \mathrm{Ti}-\mathrm{Al}$ laminated composite shows that the bending strength on the Pattern B side is $40 \mathrm{MPa}$ more than that on the Pattern A side. This is due to the fact that the volume fraction of $\mathrm{SiC}$ fiber in Pattern B is twice as much as the Pattern A side, despite there being fiber aggregation on the Pattern B side.

Table 4. Mechanical performance results of $\mathrm{Ti} / \mathrm{Ti}-\mathrm{Al}$ and $\mathrm{SiC}_{\mathrm{f}}$-reinforced $\mathrm{Ti} / \mathrm{Ti}-\mathrm{Al}$ laminated composites.

\begin{tabular}{|c|c|c|}
\hline Composites & Tensile Strength (MPa) & Flexural Strength (MPa) \\
\hline $\begin{array}{c}\mathrm{SiC}_{\mathrm{f}} \text {-reinforced } \mathrm{Ti} / \mathrm{Ti}-\mathrm{Al} \\
\text { laminated composites }\end{array}$ & $400 \pm 10$ & $\begin{array}{c}910 \pm 30 \\
\text { Pattern A stressed in tension } \\
950 \pm 30 \\
\text { Pattern B stressed in tension }\end{array}$ \\
\hline $\begin{array}{l}\mathrm{Ti} / \mathrm{Ti}-\mathrm{Al} \text { laminated } \\
\text { composites }\end{array}$ & $250 \pm 30$ & $923 \pm 10$ \\
\hline
\end{tabular}


Figure 11 presents the stress-strain curves of $\mathrm{Ti} / \mathrm{Ti}-\mathrm{Al}$ and $\mathrm{SiC}_{\mathrm{f}}$-reinforced $\mathrm{Ti} / \mathrm{Ti}-\mathrm{Al}$ laminated composites in room temperature uniaxial tension tests. The yielding strength at $0.2 \%$ deformation of the $\mathrm{Ti} / \mathrm{Ti}-\mathrm{Al}$ laminated composite is $217 \mathrm{MPa}$ and the elastic modulus is $61.17 \mathrm{GPa}$. The yielding strength at $0.2 \%$ deformation and the elastic modulus of the $\mathrm{SiC}_{\mathrm{f}}$-reinforced $\mathrm{Ti} / \mathrm{Ti}-\mathrm{Al}$ laminated composite are $339 \mathrm{MPa}$ and $101.05 \mathrm{GPa}$, respectively. Comparing to the $\mathrm{Ti} / \mathrm{Ti}-\mathrm{Al}$ laminated composite (with the same volume fraction, $60 \%$ ), the yielding strength at $0.2 \%$ deformation of $\mathrm{SiC}_{\mathrm{f}}$-reinforced $\mathrm{Ti} / \mathrm{Ti}-\mathrm{Al}$ laminated composite increases by $122 \mathrm{MPa}$, while the elastic module increases by $65 \%$. This means that by introducing the $\mathrm{SiC}$ fibers, both the tensile strength and the resistance to deformation of laminated composites are significantly improved. Meanwhile, the ultimate elongation of $\mathrm{SiC}_{\mathrm{f}}$-reinforced $\mathrm{Ti} / \mathrm{Ti}-\mathrm{Al}$ laminate composites reaches $1.6 \%$, which is about $14 \%$ higher than the Ti/Ti-Al laminate composites.

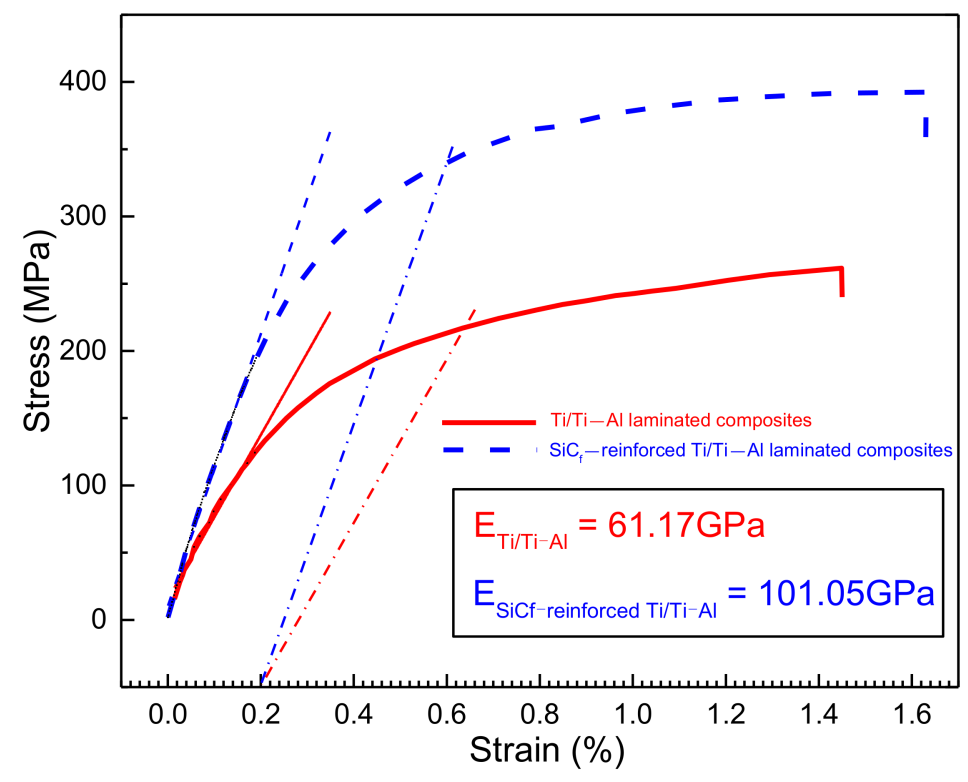

Figure 11. Stress-strain curves of the fabricated laminated composites.

Figure 12 shows the force-displacement curves of $\mathrm{SiC}_{\mathrm{f}}$-reinforced $\mathrm{Ti} / \mathrm{Ti}-\mathrm{Al}$ laminated composite obtained through in situ tensile testing. The curve consists of five stages: elastic deformation stage (I), yield stage (II), delamination stage (III), start failure stage (IV) and fracture stage $(\mathrm{V})$. The entire failure process of in situ tensile testing was observed under SEM. Figure 13 describes the detailed deformation morphologies corresponding to different tension force values. Firstly, microcracks initiated in the Ti-Al intermetallic layer when the tensile load ranged from $1002 \mathrm{~N}$ to $1102 \mathrm{~N}$, as shown in Figure 13a. As the load continued to increase, the microcracks propagated and merged in the $\mathrm{Ti}-\mathrm{Al}$ intermetallic layers. Interlayer cracks appeared when the load reached 1109 N. The microcracks and interlayer cracks first appeared in the outer layer of the laminated composite, as shown in Figure 13a,b. When the load reached $1124 \mathrm{~N}$, delamination occurred within the Ti-Al intermetallic layers (Figure 13c). Then the SiCf-reinforced Ti/Ti-Al laminated composite began to fail (Figure 13d). It can be observed that the outer layers failed first and then the inner layers (Figure 13e). Ultimately, the whole specimen fractured completely (Figure 13f). 


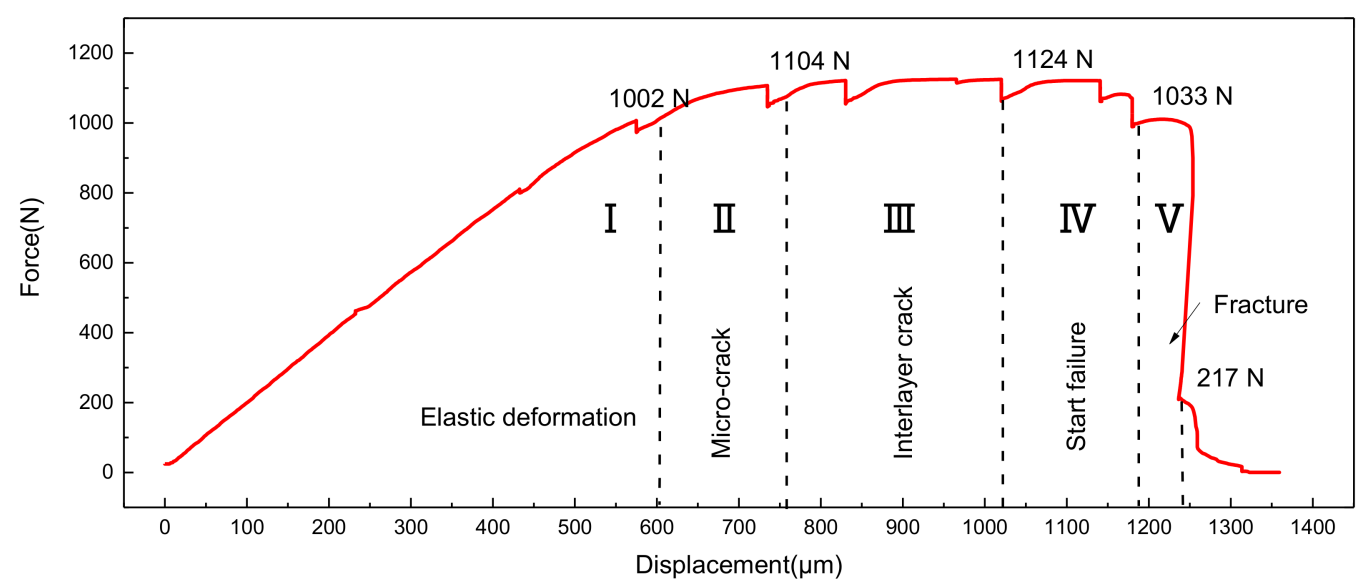

Figure 12. Force-displacement curve of $\mathrm{SiC}_{\mathrm{f}}$-reinforced $\mathrm{Ti} / \mathrm{Ti}-\mathrm{Al}$ laminate composite under in situ tensile testing.
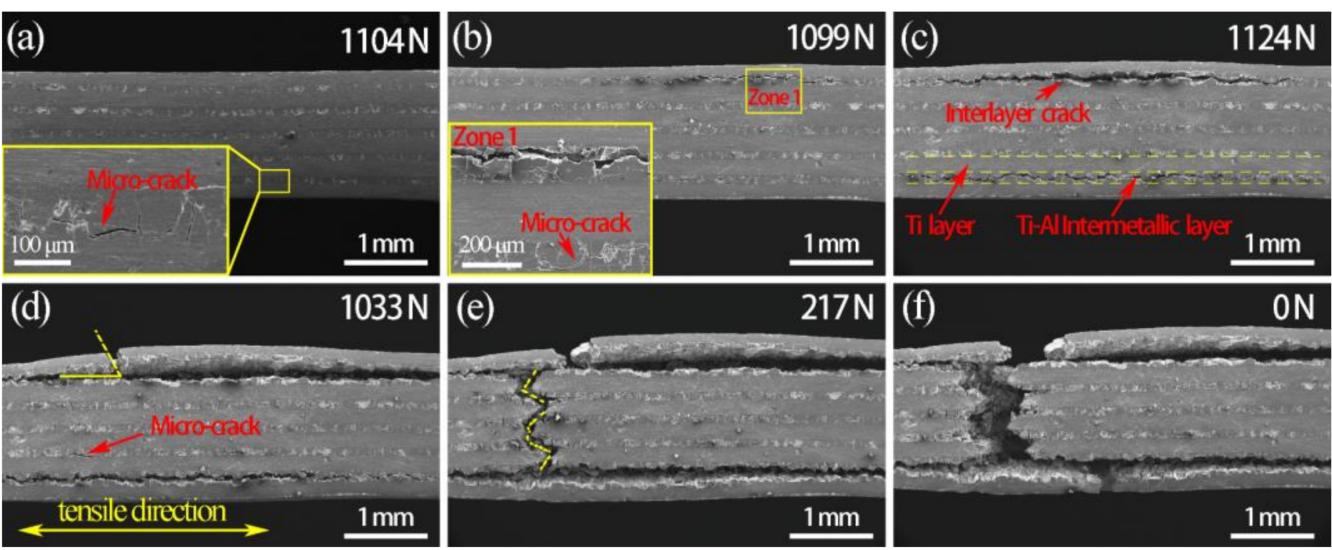

Figure 13. In situ SEM micrograph at the tensile force of (a) $1104 \mathrm{~N},(\mathbf{b}) 1119 \mathrm{~N}$, (c) $1124 \mathrm{~N}$, (d) $1033 \mathrm{~N}$, (e) $217 \mathrm{~N}$ and (f) $0 \mathrm{~N}$.

The fractures of the fabricated laminated composites are composed of the ductile fracture (Ti layer) and the brittle fracture (Ti-Al intermetallic layer). Figures 14 and 15 show the tensile fracture morphologies of $\mathrm{Ti} / \mathrm{Ti}-\mathrm{Al}$ and $\mathrm{SiC}_{\mathrm{f}}$-reinforced $\mathrm{Ti} / \mathrm{Ti}-\mathrm{Al}$ laminate composites. It can be seen that delamination was mainly generated in the Ti-Al intermetallic layer of the prepared laminated composites (Figures 14a and 15a). Both trans-granular and intergranular fractures were observed (Figure 14c). Additionally, secondary cracks (Figure 14b) emerged in the brittle Ti-Al intermetallic layer, while the Ti layer closely combined with the $\mathrm{Ti}-\mathrm{Al}$ intermetallic layer, and there is no delamination in the Ti layer (Figures 14e and 15e).

Fiber reinforcement consists of fiber pullout, fiber debonding and fiber fracture. In this experiment, it can be seen that fiber fracture was the main failure mode. Debonding of $\mathrm{SiC}$ fibers can also be observed at the interface between the fracture SiC fiber and the intermetallic matrix (Figure 15b). No pulling out failure mode was found at the fracture section, which can be ascribed to the high interface bonding strength. The excessive interface binding strength of the fibers with the matrix may limit the enhancement effect of fibers to some extent, consistent with the results in the literature [21,22]. There is no damage of the fibers in the tensile experiment (Figure 15c,f). Meanwhile, the interface between the Ti layer and the Ti-Al intermetallic layer was well integrated, which further verified that with the higher exerted pressure, more compact structures with fewer Kirkendall holes can be obtained. The conclusion can be drawn that with the introduction of the fibers, the fracture resistance of the $\mathrm{SiC}_{\mathrm{f}}$-reinforced $\mathrm{Ti} / \mathrm{Ti}-\mathrm{Al}$ laminated composites further improves. 

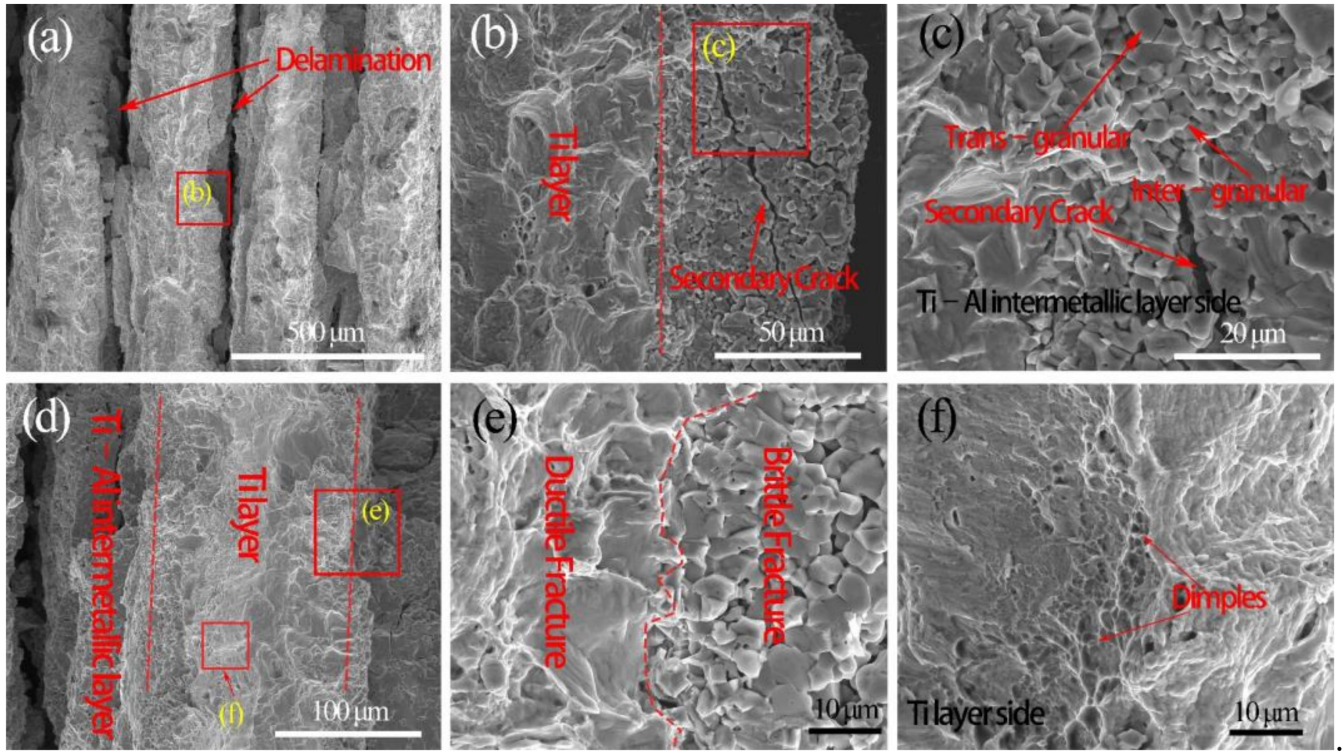

Figure 14. The tensile fracture morphologies of Ti/Ti-Al laminated composite: (a) Delamination in the Ti-Al intermetallic layer, (b) Secondary Crack in the Ti-Al intermetallic layer, (c) Trans-granular and Inter-granular in the Ti-Al intermetallic layer side, (d) Interface between Ti-Al intermetallic layer and Ti layer, (e) Interface between Ductile Fracture and Brittle Fracture, (f) Dimples in the Ti layer side.
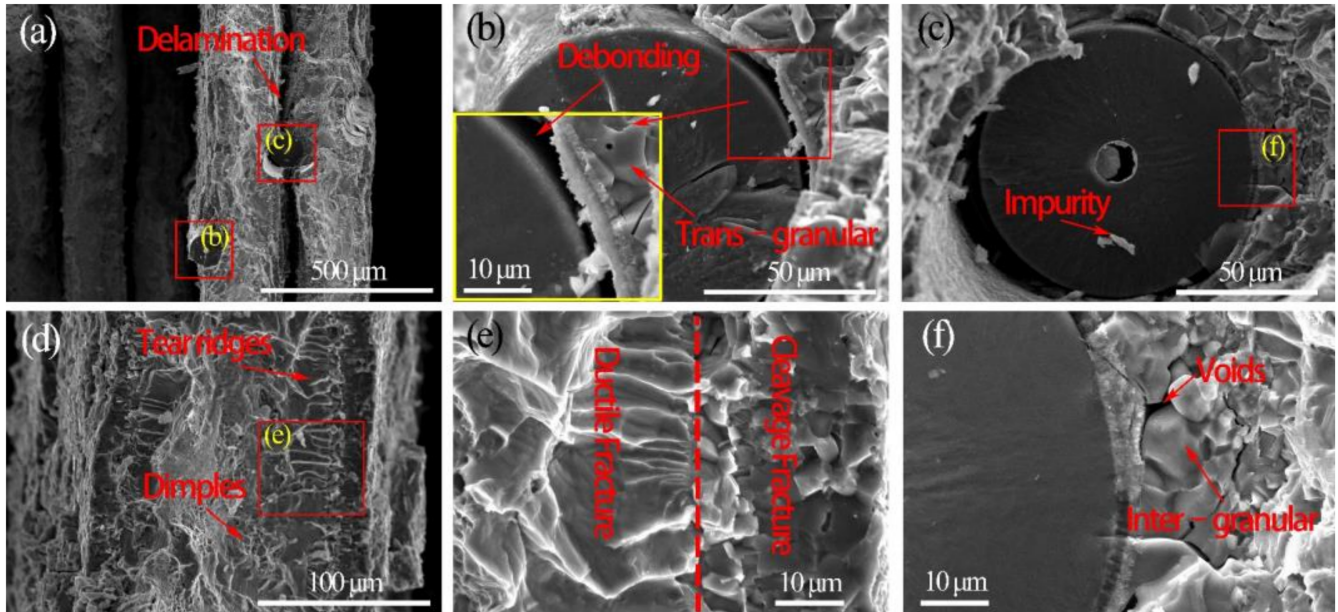

Figure 15. The tensile fracture surfaces of $\mathrm{SiC}_{\mathrm{f}}$-reinforced $\mathrm{Ti} / \mathrm{Ti}-\mathrm{Al}$ laminated composite: (a) Delamination in the Ti-Al intermetallic layer, (b) Debonding between fracture SiC fiber and the intermetallic matrix, (c) Interface between $\mathrm{SiC}$ fiber and the intermetallic matrix, (d) Dimples and Tear ridges in the Ti layer, (e) Interface between Ductile Fracture and Brittle Fracture, (f) Inter-granular in the Ti-Al intermetallic layer.

Figure 16 presents the load-deflection curves for the three-point bending test of $\mathrm{Ti} / \mathrm{Ti}-\mathrm{Al}$ and $\mathrm{SiC}_{\mathrm{f}}$-reinforced $\mathrm{Ti} / \mathrm{Ti}-\mathrm{Al}$ laminated composites. According to the results, load-deflection curves can be divided into four stages. At the beginning of loading (Stage I), the curves presented a linear increase. The flexural stiffness at this stage ranges from 87 to $\sim 104 \mathrm{GPa}$, as calculated. When the value of load reaches about $350 \mathrm{~N}$ (Stage II), the prepared laminated composites start to fail. The flexural strengths of $\mathrm{Ti} / \mathrm{Ti}-\mathrm{Al}$ and $\mathrm{SiC}_{\mathrm{f}}$-reinforced $\mathrm{Ti} / \mathrm{Ti}-\mathrm{Al}$ laminated composites are close to 900 950 MPa. It can be observed that the bending performance of laminated composites was only slightly improved due to the small amount of unidirectional $\mathrm{SiC}$ fibers introduced. 


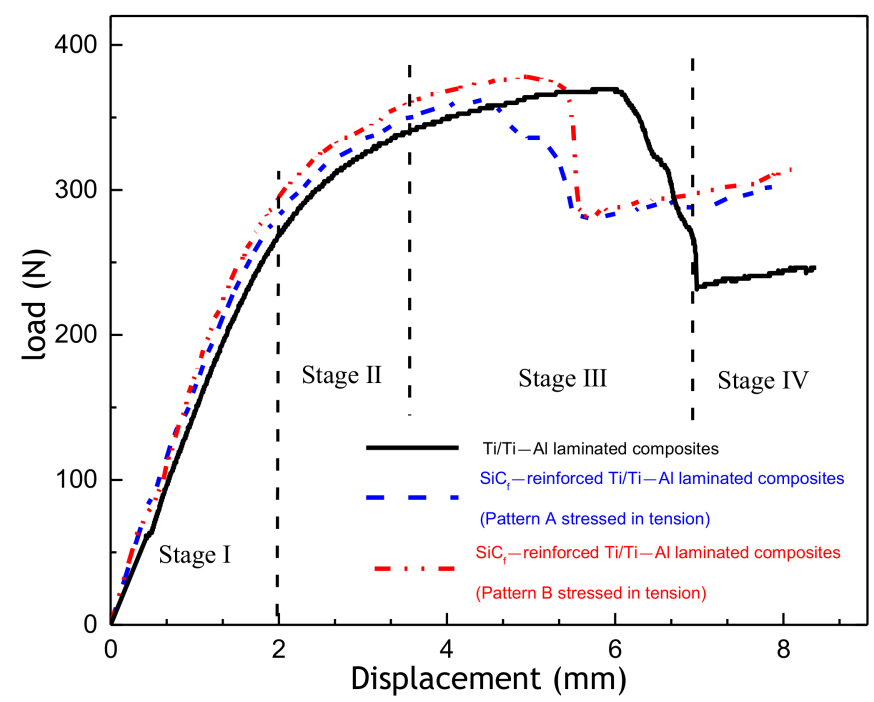

Figure 16. Load-displacement curves of the fabricated laminated composites.

Figure 17 shows the OM images of the bending crack morphologies. During the three-point bending test, delamination occurred on the tensile stress side of the prepared laminated composites. The fracture of the outermost layer played a critical role in determining the bending failure. The fracture and stripping of fibers can be observed in Figure $17 \mathrm{~d}, \mathrm{f}$.

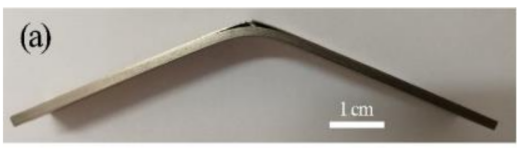

Ti/Ti-Al laminated composites

The stack sequence is $\mathrm{Ti}-\mathrm{Al}-\mathrm{Ti}$

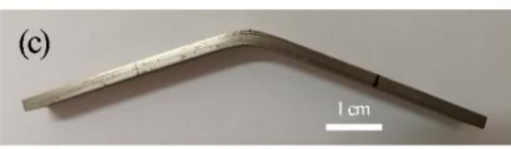

$\mathrm{SiC}_{\mathrm{f}}$-reinforced Ti/Ti-Al laminated composites (Pattem A side stressed in tension)

The stack sequence is $\mathrm{Ti}-\mathrm{Al}-\mathrm{SiC}_{\mathrm{f}}-\mathrm{Al}-\mathrm{Ti}(\mathrm{Pattem} \mathrm{A})$
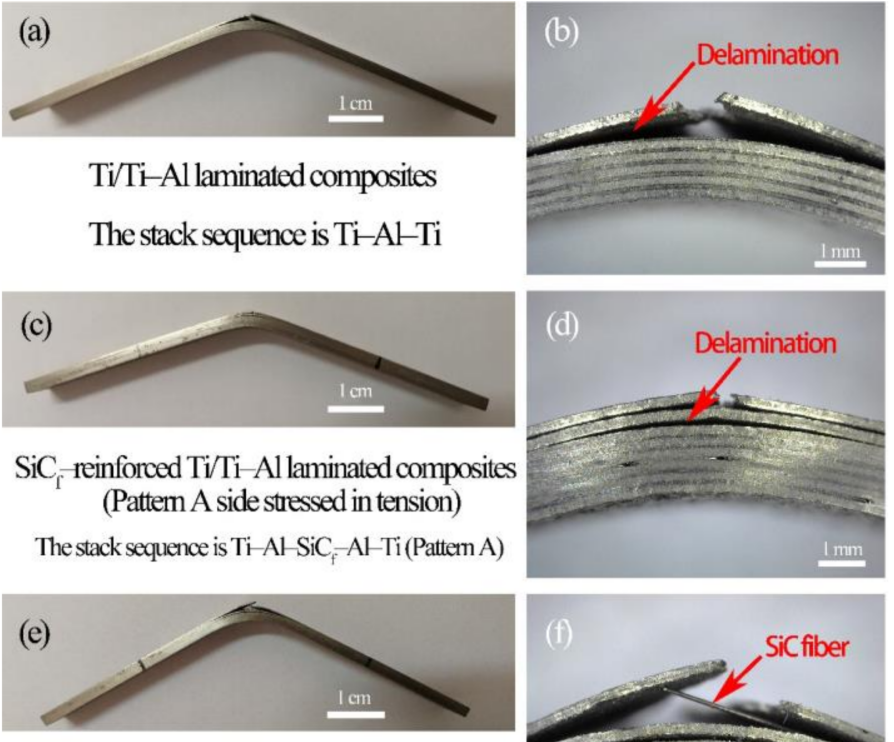

$\mathrm{SiC}_{\mathrm{r}}$-reinforced Ti/Ti-Al laminated composites (Pattem B side stressed in tension)

The stack sequence is $\mathrm{Ti}_{-} \mathrm{SiC}_{\overline{\mathrm{p}}}-\mathrm{Al}-\mathrm{SiC}_{\bar{\Gamma}}-\mathrm{Ti}$ (Pattem $\left.\mathrm{B}\right)$

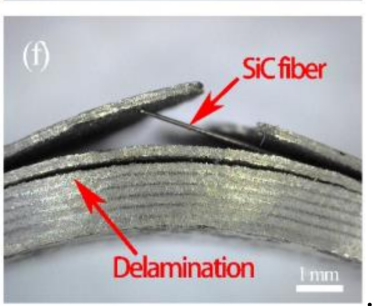

Figure 17. OM image of crack morphologies in three-point bending test: (a) and (b) Ti/Ti-Al laminated composites, (c) and (d) $\mathrm{SiC}_{\mathrm{f}}$-reinforced $\mathrm{Ti} / \mathrm{Ti}$-Al laminated composites (Pattern A side stressed in tension), (e) and (f) $\mathrm{SiC}_{\mathrm{f}}$-reinforced $\mathrm{Ti} / \mathrm{Ti}$-Al laminated composites (Pattern $\mathrm{B}$ side stressed in tension).

Figure 18 shows the bending crack morphologies of the fabricated laminated composites. Firstly, the microcracks in the Ti-Al intermetallic layers initiated parallel to the loading direction (Figure 18b,e,g). Subsequently, the microcracks continued to spread to the Ti layer. Because of the obstruction of the ductile titanium layer, the crack tip blunted and did not continued to spread in the Ti layer (Stage I, Figure 18c,e,g). With the increase 
in load (Stage II), more microcracks were generated. With the microcracks' growth and merging, long cracks parallel to the laminate structure emerged. These cracks propagating in the Ti-Al intermetallic layers led to the delamination of laminated composites. The propagation path of the cracks was long and zigzagged (Stage III, Figure 18a,d,f), which indicates a better absorption of fracture energy.
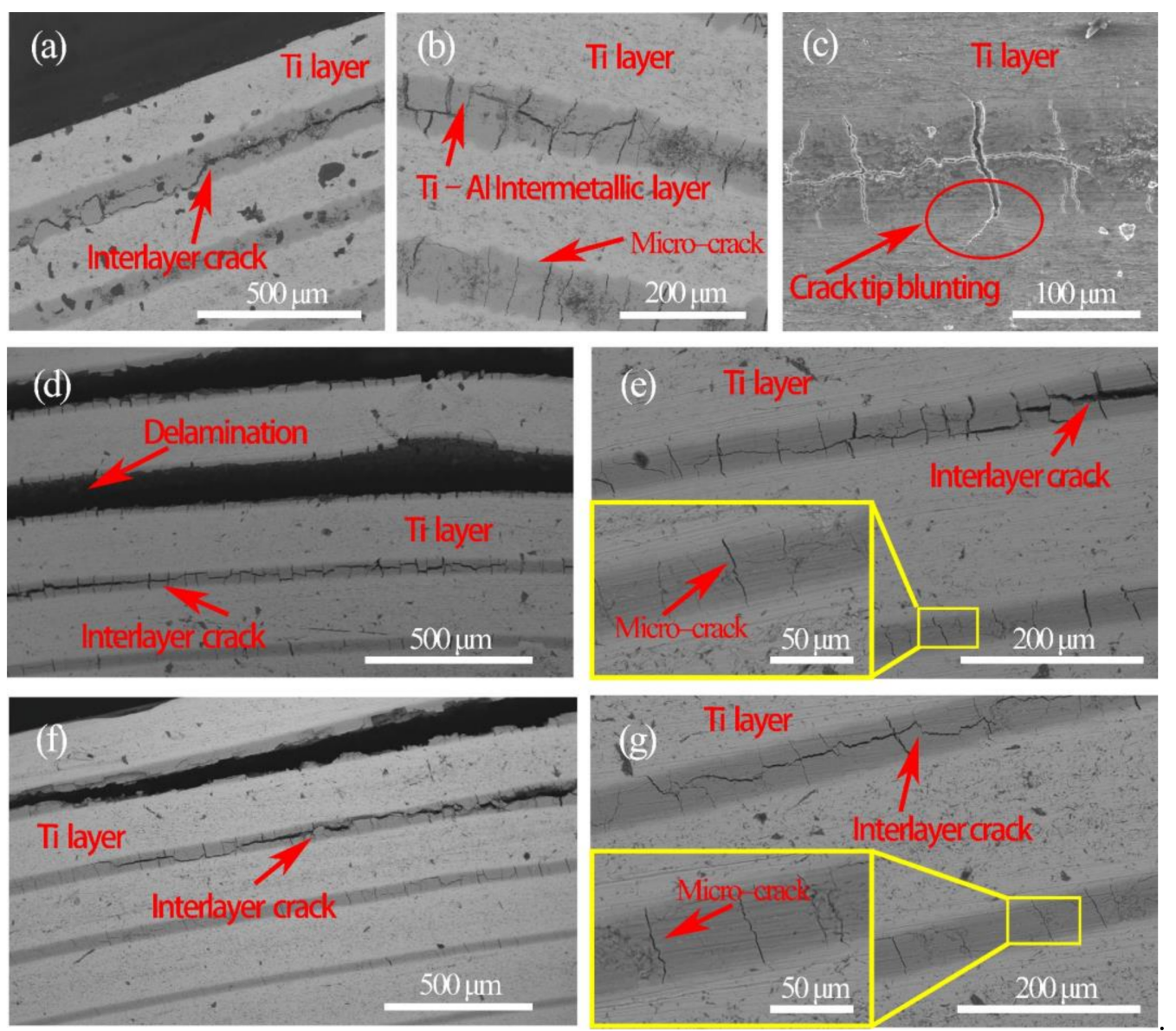

Figure 18. The crack morphologies of the prepared laminated composites in three-point bending test: $(\mathbf{a}-\mathbf{c}) \mathrm{Ti} / \mathrm{Ti}-\mathrm{Al}$ Laminated Composite; $(\mathbf{d}-\mathbf{g}) \mathrm{SiC}_{\mathrm{f}}$-reinforced Ti/ Ti-Al laminated composites, (d) and (e) Pattern A stressed in tension, (f) and (g) Pattern B stressed in tension.

\section{Conclusions}

$\mathrm{Ti} / \mathrm{Ti}-\mathrm{Al}$ and $\mathrm{SiC}_{\mathrm{f}}$-reinforced $\mathrm{Ti} / \mathrm{Ti}-\mathrm{Al}$ laminated composites were fabricated through vacuum hot-pressure, and the effects of $\mathrm{SiC}$ fiber and laminated structure on the properties of Ti-Al laminated composites were studied. The main conclusions are presented as follows:

1. Equal spacing of the fibers could be guaranteed for $\mathrm{SiC}_{\mathrm{f}}$-reinforced $\mathrm{Ti} / \mathrm{Ti}-\mathrm{Al}$ laminated composites prepared by a novel method of fiber weaving. No other elements would be introduced to contaminate the composites.

2. With the higher exerted pressure, more compact structure with fewer Kirkendall holes could be obtained in $\mathrm{SiC}_{\mathrm{f}}$-reinforced $\mathrm{Ti} / \mathrm{Ti}$-Al laminated composites.

3. $\mathrm{SiC}_{\mathrm{f}}$-reinforced $\mathrm{Ti} / \mathrm{Ti}-\mathrm{Al}$ laminated composites had a tensile strength of $400 \pm 10 \mathrm{MPa}$ and flexural strength of $900 \sim 950 \mathrm{MPa}$. Compared to Ti/Ti-Al laminates, the tensile strength increased by $60 \%$, while the ultimate elongation reached $1.6 \%$ (increased by about $14 \%$ ). The flexural strength did not change much (Ti/Ti-Al laminate composites had a flexural strength of $923 \pm 10 \mathrm{MPa}$ ). The tensile properties of the laminated composites could be effectively improved by introducing the $\mathrm{SiC}$ fibers, while the 
bending properties were not obviously influenced due to the small volume fraction of fibers.

4. The deformation behavior and fracture mechanisms of $\mathrm{SiC}_{\mathrm{f}}$-reinforced $\mathrm{Ti} / \mathrm{Ti}-\mathrm{Al}$ laminated composites were obtained through in situ tensile tests. Microcracks first occurred in the Ti-Al intermetallic layer. With the growth and merging of microcracks, interlayer cracks formed in the Ti-Al intermetallic layer along the load direction.

Author Contributions: Conceptualization, S.Z. and C.H; methodology, Z.M.; software, C.H.; investigation, C.H. and Z.M.; data curation, B.L. and Z.W.; writing - original draft preparation, S.Z. and C.H.; writing-review and editing, B.L.; supervision, S.Z.; project administration, S.Z.; funding acquisition, S.Z. and Z.W. All authors have read and agreed to the published version of the manuscript.

Funding: This work was funded by the National Natural Science Foundation of China (Grant No.: 51875444) and National Defense Basic Research Program (Grant No.: JCKY2019204A001).

Institutional Review Board Statement: Not applicable.

Informed Consent Statement: Not applicable.

Data Availability Statement: Data sharing not available.

Conflicts of Interest: We declare that we have no financial and personal relationships with other people or organizations that can inappropriately influence our work, there is no professional or other personal interest of any nature or kind in any product, service and/or company that could be construed as influencing the position presented in, or the review of, the manuscript entitled "Effects of $\mathrm{SiC}$ fibers and laminated structure on mechanical properties of Ti-Al laminated composites".

\section{References}

1. Djanarthany, S.; Viala, J.C.; Bouix, J. An overview of monolithic titanium aluminides based on $\mathrm{Ti}_{3} \mathrm{Al}$ and TiAl. Mater. Chem. Phys. 2001, 72, 301-319. [CrossRef]

2. Bewlay, B.P.; Nag, S.; Suzuki, A.; Weimer, M.J. TiAl alloys in commercial aircraft engines. Mater. High Temp. 2016, 33, 549-559. [CrossRef]

3. Ward-Close, C.M.; Minor, R.; Doorbar, P.J. Intermetallic-matrix composites-A review. Intermetallics 1996, 4, 217-229. [CrossRef]

4. Zhu, K.; Yu, W.B.; Aman, Y.; Jing, T. Synthesis, microstructure and mechanical properties of a bio-inspired Ti-intermetallic multi-layered $/ \mathrm{SiC}_{\mathrm{f}}$-reinforced Ti-matrix hybrid composite. J. Mater. Sci. 2016, 51, 8747-8760. [CrossRef]

5. Ai, T.T.; Niu, Q.F.; Deng, Z.F.; Li, W.H.; Dong, H.F.; Jing, R.; Zou, X.Y. Nature-inspired nacre-like Ti6Al4V-(Ti2AlC/TiAl) laminate composites combining appropriate strength and toughness with synergy effects. Intermetallics 2020, 121, 106774.

6. Lyu, S.Y.; Sun, Y.B.; Ren, L.; Xiao, W.L.; Ma, C.L. Simultaneously achieving high tensile strength and fracture toughness of $\mathrm{Ti} / \mathrm{Ti}-\mathrm{Al}$ multilayered composites. Intermetallics 2017, 90, 16-22. [CrossRef]

7. Gao, K.; Zhang, X.; Liu, B.; He, J.; Feng, J.; Ji, P.; Fang, W.; Yin, F. The Deformation Characteristics, Fracture Behavior and Strengthening-Toughening Mechanisms of Laminated Metal Composites: A Review. Metals 2020, 10, 4. [CrossRef]

8. Li, T.Z.; Al Olevsky, E.; Meyers, M.A. The development of residual stresses in Ti6Al4V-Al 3 Ti metal-intermetallic laminate (MIL) composites. Mater. Sci. Eng. Struct. Mater. Prop. Microstruct. Process. 2008, 473, 49-57. [CrossRef]

9. Chaudhari, G.P.; Acoff, V.L. Titanium aluminide sheets made using roll bonding and reaction annealing. Intermetallics 2010, 18, 472-478. [CrossRef]

10. Lazurenko, D.V.; Mali, V.I.; Bataev, I.A.; Thoemmes, A.; Bataev, A.A.; Popelukh, A.I.; Anisimov, A.G.; Belousova, N.S. MetalIntermetallic Laminate Ti-Al3Ti Composites Produced by Spark Plasma Sintering of Titanium and Aluminum Foils Enclosed in Titanium Shells. Metall. Mater. Trans. A 2015, 46, 4326-4334. [CrossRef]

11. Vecchio, K.S. Synthetic multifunctional metallic-intermetallic laminate composites. JOM 2005, 57, 25-31. [CrossRef]

12. Zhang, W.; Yang, Y.Q.; Zhao, G.M.; Feng, Z.Q.; Huang, B.; Luo, X.; Li, M.H.; Chen, Y.X. Interfacial reaction studies of B4C-coated and C-coated $\mathrm{SiC}$ fiber reinforced Ti-43Al-9V composites. Intermetallics 2014, 50, 14-19. [CrossRef]

13. Yu, W.; Zhu, K.; Aman, Y.; Guo, Z.; Xiong, S. Bio-inspired design of SiCf-reinforced multi-layered Ti-intermetallic composite. Mater. Des. 2016, 101, 102-108. [CrossRef]

14. Wang, P.C.; Her, Y.C.; Yang, J.M. Fatigue behavior and damage modeling of SCS-6/titanium/titanium aluminide hybrid laminated composite. Mater. Sci. Eng. A 1998, 245, 100-108. [CrossRef]

15. Zhang, G.; Yuan, M.; Li, S.; Hou, H.; Qu, H.; Zhao, B. Fabrication and Interface Reaction of SiC Fiber Reinforced Ti/Ti2AlNb Laminated Composite. Chin. J. Rare Metals 2017, 41, 1093-1098.

16. Lin, C.F.; Wang, S.Y.; Yan, H.R.; Han, Y.Q.; Zhu, J.Y.; Shi, H. Optimization Mechanisms of Microstructure and Mechanical Properties of SiC Fiber Reinforced Ti/Al3Ti Laminated Composite Synthesized Using Titanium Barrier. Met. Mater. Int. 2021, 306-318. [CrossRef] 
17. Khoshhal, R.; Soltanieh, M.; Mirjalili, M. Formation and growth of titanium aluminide layer at the surface of titanium sheets immersed in molten aluminum. Iran. J. Mater. Sci. Eng. 2010, 7, 24-31.

18. Tavoosi, M. The Kirkendall void formation in $\mathrm{Al} / \mathrm{Ti}$ interface during solid-state reactive diffusion between $\mathrm{Al}$ and Ti. Surf. Interfaces 2017, 9, 196-200. [CrossRef]

19. Xu, L.; Cui, Y.Y.; Hao, Y.L.; Yang, R. Growth of intermetallic layer in multi-laminated Ti/Al diffusion couples. Mater. Sci. Eng. Struct. Mater. Prop. Microstruct. Process. 2006, 435, 638-647. [CrossRef]

20. Han, Y.Q.; Jiang, F.C.; Lin, C.F.; Yuan, D.; Huang, H.; Wang, E.H.; Wang, Z.Q.; Guo, C.H. Microstructure and mechanical properties of continuous ceramic $\mathrm{SiC}$ and shape memory alloy NiTi hybrid fibers reinforced Ti-Al metal-intermetallic laminated composite. J. Alloys Compd. 2017, 729, 1145-1155. [CrossRef]

21. Lin, C.F.; Han, Y.Q.; Guo, C.H.; Chang, Y.P.; Han, X.X.; Lan, L.; Jiang, F.C. Synthesis and mechanical properties of novel Ti(SiCf/Al3Ti) ceramic-fiber-reinforced metal-intermetallic-laminated (CFR-MIL) composites. J. Alloys Compd. 2017, 722, 427-437. [CrossRef]

22. Baik, K.H. Tensile Failure Behavior of SiC/Ti-6Al-4V Composites Manufactured by Plasma Spraying Route. Mater. Trans. 2006, 47, 2815-2820. [CrossRef] 